\title{
The Origin and Formation of Quasi-judicial Institutions of Social Control as Elements of Civil Society
}

\author{
Alla Fakurdinova ${ }^{1},{ }^{*}$ Olga Kopylova ${ }^{2}$, Svetlana Medvedeva ${ }^{2}$, Bella Tskhovrebova ${ }^{1}$ \\ ${ }^{1}$ Institute of International Economic Relations, Moscow, Russia \\ ${ }^{2}$ Tambov State Technical University, Tambov, Russia \\ "Email:19alla9120081@ rambler.ru
}

\begin{abstract}
The article is devoted to analysing the chronological periodisation of the origin and formation of elements of quasijudicial justice in the history of the Russian state and covers the time from the early feudal forms of ancient Russian statehood to the beginning of the 20th century. The quasi-judicial institutions' elements (elements of administrative justice, the monarch's will, corporate public institutions endowed with judicial powers, elements of arbitration proceedings) are summarised. The source basis was the large normative legal systematisation of medieval law (Russian Truth (Russkaya Pravda), Judicial Code (Sudebnik) of 1497 and 1550, the Cathedral Code (Sobornoe Ulozhenie) of 1649), the systematisation of commercial law and acts of local government and self-government. Based on the analysis of the process of the emergence of quasi-judicial elements within the framework of the public administration system and the periods of its active modernisation, it is concluded that it is possible to distinguish four chronological periods of their formation; it is concluded that quasi-judicial functions are used for administrative control.
\end{abstract}

Keywords: Quasi-judicial institutions, Complaint, Justice, Periodisation, Administrative justice.

\section{INTRODUCTION}

Quasi-judicial institutions are widespread in the history of forms of social control. The prefix "quasi" (i.e. "pseudo") in this case means such forms of justice that imply judicial functions assigned in a state of law exclusively to judicial authorities, performed nevertheless by non-judicial institutions of both state and public (corporate) origin.

Ancient justice systems were often based on a community court, a court of equals, elders, elected members. This popular power element - evidence of primitive tribal democracy is found in the history of all peoples whose past historians manage to trace in retrospect to the state period of formation. The cities of Western Europe, which built their judicial principles based on commerce, had corporate communities with judicial powers, which often existed as liberty, as opposed to the justice of the monarch.
The relevance of the research topic is because, for the first time in the National history and the history of law, the emergence of the first quasi-judicial bodies as elements of civil society of the pre-revolutionary period is considered.

The article uses the following methods: retrospective, chronologically problematic, periodisation, source analysis. In the study of normative legal acts of that time, their systematisation was carried out, and the normative legal acts themselves were considered a complete holistic statement of the legislator's will at a particular historical time.

\section{THE APPEARANCE OF THE FIRST QUASI-JUDICIAL BODIES}

When the Russian Truth of Yaroslav the Wise was adopted, the Prince, who acted as the principal administrative and judicial body in Russia, carried out the trial [1, pp. 27-80]. 
Since the Prince had extensive powers, the fines imposed during the consideration of cases and the property of the convicted person ultimately passed into the possession of Prince, this fact shows us that the conduct of justice in Russia had, among other things, the most important goal - to replenish the treasury of the Prince. Russian Truth was included in all legal collections up to the 16 th century.

In his publication "Mittelalterliches nordisches Recht bis 1500: Eine Quellenkunde", Dieter Strauch noted a significant influence of Scandinavian law in Russian Truth, which is characteristic of the period of adoption of this document [2]. Russian language professor in France W. Vodoff was also studying Russian Truth. He emphasised the complexity of translating the "judicial code" terminology in modern law [3, p. 484].

The judicial system as a whole took shape during the period of centralisation. An essential stage in the history of Russian judicial law is the emergence of the Judicial Code (Sudebnik) of Ivan III in 1497. This document is, in fact, the first general Judicial Code, which covers in detail the process of conducting investigations and trials in civil and criminal cases. In the Judicial Code of 1497, the right to file a complaint was clearly defined: "And what kind of complainer will come to the boyar, and do not send him complainers from yourself, but give all the complainer a board in everything suitable. And which complainer is not fit to manage, and then tell the Grand Prince, or forward him to one whom some people are ordered to lead" [4]. This act actually gives rise to administrative justice.

During the period of the Grand Duchy of Moscow, quasi-judicial procedures include the ancient right to submit a petition to the tsar personally, a request for mercy, including a complaint against an unreasonable court decision. For the consideration of complaints, there was a Petition Order, which currently, using modern terminology, can be attributed to administrative justice bodies. The order served as the secretariat of the tsar, his personal office [5].

The grace of the supreme ruler, who had the opportunity and will to cancel a court sentence- is a natural phenomenon in the conditions of a classrepresentative and absolute monarchy, generated by the concept of the priority of the monarch's will among all sources of law.

A further crucial legislative act, which appeared in 1649, is the Cathedral Code (Sobornoe Ulozhenie), which fixed at the legislative level the responsibility of officials for violating the procedure for considering a complaint. The Cathedral Code of 1649, for the first time at the legislative level, consolidated the force of an arbitration decision, i.e. a decision coming from a person whom both parties trust and are ready to obey, such a decision equated it to a state decision [6].
In 1667, according to the New Trade Charter, customs courts were put into effect as one of the quasijudicial bodies [7].

During the reign of Peter I, the Boyar Duma ceased to exist, and the Senate was established, where complaints about governors were brought. Also, during the reign of Peter I, a Commercial Board was formed, whose jurisdiction included trade and bill affairs; a Chief magistrate appeared, considering trade cases, including tax and customs.

The Chief Magistrate determined the composition of the verbal court, which contributed to the reconciliation of the disputing parties. The verbal court considered cases related to the payment of trade duties. Another type of corporate trading instance was the Merchant Court. Thus, during the reign of Peter I and his successors, various quasi-judicial bodies appeared, particularly economic ones. These courts were not created systematically, appearing now in some, then in other regions, they were different in composition, number, subject of activity, nature of justice and consideration of various categories of cases.

In 1763, the Senate was reorganised and divided into departments. It became at the same time a governmental, judicial and administrative body, whose main functions were control, trial and examination of complaints against all other governing bodies.

In the era of Catherine II, there was the phenomenon of the "conscientious court" (1775). For criminal proceedings, they were involved in a situation where leniency was required for a criminal due to his infancy, distress; for civil proceedings, they played the role of arbitration, i.e. they carried the features of quasi-judicial.

\section{THE ORIGIN OF ADMINISTRATIVE JUSTICE IN THE FIRST HALF OF THE 19TH CENTURY}

Administrative justice as a complex of judicial and quasi-judicial procedures theoretically began to be considered in Russian legal thought in the first half of the 19 th century.

At the same time, the first half of the 19th century is the time of comprehension of the phenomenon of nonstate judicial proceedings and even experiments in this legal field.

Given the various administrative status of numerous national territories of the Russian Empire, which largely preserved customs and legislation that was not fully unified, elements of non-state arbitration can be seen in the Provisions that defined the system of power and assimilation in the lands of the Don Army. The nomadic peoples of the Caucasus (Nogais) in 1827 received the right to resolve lawsuits according to their customs through Islamic intermediaries and elders [8]. 
After the systematisation of law in the first third of the 19th century, the Charter of Commercial Legal Proceedings was created, based on which commercial courts defended merchant interests. The first Russian Commercial Court was founded in Odessa in 1808, then appeared in all major fairground and port cities. Commercial courts were a kind of judicial hybrids by their legal nature since they were organised on a mixed basis.

In the post-reform period, there was a separation of the judiciary into a separate branch (the independence of this branch of government, as well as the rest, is the subject of independent analysis, considering the conditions of the absolute monarchy in which the judicial reform of the 1860 s took place).

The post-reform legislation contained a clear list of judicial bodies: "Judicial power belongs to justices of the peace, congresses of justices of the peace, district courts, judicial chambers and the governing Senate as the Supreme Cassation Court" [9].

Accordingly, highlighting the bodies and institutions with judicial powers and this list makes it possible to identify a set of quasi-judicial structures.

The Tsarist government, mainly for political reasons, constantly established quasi-judicial bodies or gave judicial powers to officials and executive authorities.

So, the zemstvo chiefs had quasi-judicial powers. The Institute of zemstvo chiefs is one of the foundations of the counter-reform process of the $1880 \mathrm{~s}-90 \mathrm{~s}$ and "... although to a limited extent, the old pre-statutory combination of administrative and judicial functions in one person ..." [10].

The zemstvo chiefs were subordinated to the Ministry of Internal Affairs (Articles 15-18 of the Regulations on Zemstvo Chiefs) [11]. According to the Regulations, their sentences were not subject to appeal.

The volost court, the estate peasant judicial body, was significant in the volume of cases under consideration. This court acted based on electability in each parish, dealt with minor lawsuits and misdemeanours [12].

The peculiarity was that the source of the court decision was the area's custom; the procedures were also outside the legislative framework. For foreigners, there were lower foreign courts (which had different names and retained national origin), similar in form to the peasant volost court.

Quasi-judicial powers also had the Combined Presence I and Cassation Departments of the Senate and the Minister of Justice [13]. Governors, as the highest officials in the regional power structure. Along with the Governor-General, they had the right to change the jurisdiction of cases.
Governors, Governors-General and the Minister of Internal Affairs could refer cases against "persons of the civil department" to military courts for committing any crime. They also determined the regime of courtspeaking in a military court (open or closed), supervised the movement of the case, decided on the direction (or non-direction) of the verdict of the military court to cassation and its approval [14].

The Corps of gendarmes had significant powers within the framework of activities defined as judicial (investigation of state crimes, which replaced the preliminary investigation).

By the end of the 19th century, the need for administrative justice was generally recognised. At the same time, this concept theoretically, doctrinally included both a model of the activity of administrative courts, which would be such formally and quasi-judicial administrative bodies.

At the turn of the century, two kinds of state institutions were called as "similarity" of administrative justice bodies:

The first kind included the 1st Department of the Senate, which formally acted as an administrative court.

To the second kind I. Tarasov also referred to the local military service presences formed following the Statute on Military Service of January 1, 1874 [15, p. 61].

Although the local military service presences, like other quasi-judicial bodies, did not meet the theory of administrative justice requirements, practice shows that the applicants quite often turned to it as an administrative and judicial body.

\section{CONCLUSION}

Thus, having isolated quasi-judicial institutions in the flow of historical normative and state-organisational material, which performed along with judicial functions of social control, we come to the following conclusions and generalisations.

The chronological periodisation of the formation of these institutions as elements of civil society can be distinguished based on traditional, generally accepted periods in the history of pre-revolutionary Russian statehood:

- the period of the origin of the state-forming elements (courts, administration) and the preservation of community management institutions (before the 16th century);

- the period of active transformations of the era of the formation of the absolutist state - from the adoption of the Cathedral Code to the provincial reform of Catherine II inclusive (the active introduction characterised this period by the state of essentially quasi-judicial public 
institutions - corporate courts - under the influence of the ideas of Enlightenment and the "state of the common good");

- the first half of the 19th century, the pre-reform period, was characterised by a gradual expansion of the theoretical understanding of administrative justice, systematisation and widespread introduction of corporate arbitration in the private commercial sphere;

- the post-reform period, characterised primarily by the ability to identify quasi-judicial institutions accurately as opposed to specified judicial authorities, the use of quasi-judicial functions as a legal mechanism of "counter-reform" (for example, in the field of limiting local self-government)

The main problems in the formation of the first quasijudicial bodies, as elements of civil society, are the following: inequality of citizens (the tsar and employees (peasants, boyars, nobles, princes, merchants, burghers, serfs)), life and customs of various segments of the population, values, lack of democracy, territorial disunity, the permissiveness of the tsar, lack of punishments.

Identifying quasi-judicial organs and quasi-judicial functions in the materials of the pre-revolutionary era is of particular scientific value since it is the first comprehensive study of quasi-organs of that time.

\section{REFERENCES}

[1] Russian Truth [Russkaya pravda] // Library of literature of Ancient Russia in 20 volumes [Biblioteka literatury Drevnej Rusi v 20 tomah], St. Petersburg: Nauka 4 (1997) 679.

[2] D. Strauch, Mittelalterliches nordisches Recht bis 1500: Eine Quellenkunde / D. Strauch // Reallexikon der Germanischen Altertumskunde Ergänzungsbände, Berlin: Walter de Gruyter 73 (2011) 886.

[3] W. Vodoff, Histoire et philologie russes / W. Vodoff, Electronic text data. Mode of access: https://www.persee.fr/doc/ephe_0000$\underline{0001 \_1974 \text { num } 11 \_1 \_6018}$

[4] Judicial Code of 1497 [Sudebnik 1497]. URL: http://www.studfiles.ru/preview/6267304/page:2/

[5] N.P. Eroshkin, The history of state institutions of pre-revolutionary Russia: A textbook for students of higher educational institutions specialising in Historical and Archival Studies [Istoriya gosudarstvennyh uchrezhdenij dorevolyucionnoj Rossii: Uchebnik dlya studentov vysshih uchebnyh zavedenij po special'nosti «Istorikoarhivovedenie»], Moscow: Higher School, 1983, $352 \mathrm{p}$.
[6] The Cathedral Code 1649, According to the edition: The Cathedral Code of 1649 [Sobornoe Ulozhenie. 1649 g. Po izdaniyu: Sobornoe ulozhenie 1649 goda] / Edited by M.N. Tikhomirov, P.P. Epifanov, Moscow: Moscow University Publishing House, 1961.

URL: http://krotov.info/acts/17/2/ulozhen1.html

[7] New Trade Charter [Novotorgovyj Ustav]. URL: http://www.hist.msu.ru/ER/Etext/novotorg.htm

[8] I.V. Lidzhieva, "The Charter for the management of the Nogais and other Mohammedans, wandering in the Caucasus region" as a source on the history of the nomadic steppe natives of the Caucasus [«Ustav dlya upravleniya nogajcami i drugimi magometanami, kochuyushchimi v Kavkazskoj oblasti» kak istochnik po istorii kochevyh inorodcev stepnogo predkavkaz'ya] // Magna adsurgit: historia studiorum, No. 1, 2017. URL: http://kigiran.com/pubs/index.php/history/article/vi ew/1038/1351

[9] Judicial statutes of November 20, 1864, with a statement of the reasoning they are based, issued by the State Chancellery [Sudebnye ustavy 20 noyabrya 1864 goda s izlozheniem rassuzhdenij, na koih oni osnovany, izdannye Gosudarstvennoyu Kancelyarieyu], The second expanded edition. In IV parts, Part III, St. Petersburg: Printing House of II Branches Of His Imperial Majesty's Own Chancellery [Vtoroe dopolnennoe izdanie, V IV chastyah. CH.III. SPb.: Tipografiya II Otdeleniya SEIV Kancelyarii], 1867, p. 13. URL: http://civil.consultant.ru/sudeb_ustav/

[10] A.V. Vereshchagina, Ways to limit the independence of the judiciary in pre-revolutionary legislation [Sposoby ogranicheniya samostoyatel'nosti sudebnoj vlasti v dorevolyucionnom zakonodatel'stve] // Law and Politics [Pravo i politika], No. 7(175), 2014.

[11] Regulations on Zemstvo precinct chiefs [Polozhenie o zemskih uchastkovyh nachal'nikah] / Collection of laws and orders of the Government, issued under the Governing Senate [Sobranie uzakonenij i rasporyazhenij pravitel'stva, izdavaemoe pri Pravitel'stvuyushchem Senate], St. Petersburg 81 (1889) 1373-1418.

[12] On the transformation of local peasant institutions and the judicial part in the Empire: A nominal decree was given to the Senate on July 12, 1889 , No. 6195 // (The Complete Collection of Laws of the Russian Empire (PSZRI), SPb.: Printing House of II Branches Of His Imperial Majesty's Own Chancellery. 1886. Assembly III, Vol. IX; Rules on the Procedure for putting into Effect the 
Regulations on Zemstvo Chiefs: The Opinion of the State Council, Most Highly approved on July 12, 1889, No. 6196 // PSZRI. SPb.: Printing House of II Branches Of His Imperial Majesty's Own Chancellery, 1886, Assembly III, Vol. IX [O preobrazovanii mestnyh krest'yanskih uchrezhdenij i sudebnoj chasti v Imperii: Imennoj, dannyj Senatu ukaz ot 12 iyulya 1889 goda, № 6195 // (Polnoe Sobranie Zakonov Rossijskoj Imperii (PSZRI). $\mathrm{SPb} .:$ Tip. II Otdeleniya Sobstvennoj Ego Imperatorskogo Velichestva Kancelyarii. 1886. Sobranie III. T. IX; Pravila o poryadke privedenie v dejstvie Polozheniya o zemskih nachal'nikah: Mnenie Gosudarstvennogo Soveta Vysochajshe utverzhdennoe 12 iyulya 1889 goda, № 6196 // PSZRI, SPb.: Tip. II Otdeleniya Sobstvennoj Ego Imperatorskogo Velichestva Kancelyarii, 1886, Sobranie III. T.IX.]

[13] On the procedure for issuing a General Order to Judicial Regulations and on the disciplinary responsibility of the ranks of the judicial department: The most highly approved opinion of the State Council of May 20, 1885, No. 2959 // PSZRI, SPb.: Printing House of II Branches Of His Imperial Majesty's Own Chancellery, 1886, Assembly III, Vol. V [O poryadke izdaniya Obshchego Nakaza sudebnym ustanovleniyam i o disciplinarnoj otvetstvennosti chinov sudebnogo vedomstva: Vysochajshe utverzhdennoe mnenie Gosudarstvennogo Soveta ot 20 maya 1885 goda. № 2959 // PSZRI. SPb.: Tip. II Otdeleniya Sobstvennoj Ego Imperatorskogo Velichestva Kancelyarii, 1886. Sobranie III. T.V.].

[14] A.V. Vereshchagina, Ways to limit the independence of the judiciary in pre-revolutionary legislation [Sposoby ogranicheniya samostoyatel'nosti sudebnoj vlasti v dorevolyucionnom zakonodatel'stve] // Law and Politics [Pravo i politika], No. 7(175), 2014.

[15] I.T. Tarasov, The organisation of administrative justice [Organizaciya administrativnoj yusticii] // Legal Bulletin [Yuridicheskij vestnik] 9 (1887) 61. 